\title{
Radial Artery Cannulation at the Anatomical Snuffbox: Hype or Hope in Interventional Cardiology?
}

\author{
Gökay Taylan®, Cihan Öztürk®, Kenan Yalta® \\ Department of Cardiology, Trakya University School of Medicine, Edirne, Turkey
}

To the Editor,

A distal radial artery access site (namely, anatomical snuffbox) has been suggested as an alternative anatomical region for radial artery cannulation in patients undergoing coronary angiogram $(\mathrm{CAG})$ or percutaneous coronary intervention (PCI). ${ }^{1-4}$ In their recently published article, ${ }^{1}$ Soydan et al. have demonstrated the potential feasibility of left anatomical snuffbox in the setting of primary PCI. We agree on the potential benefits of performing PCI through arterial cannulation at the anatomical snuffbox. However, we would like to make a few comments on their study findings ${ }^{1}$ and implications of this novel access site in the clinical setting:

First, it may not be possible to draw firm conclusions regarding the absolute safety of this access site in female patients as they only constitute $13 \%$ of total study subjects (4 patients) in the current study. ${ }^{1}$ Similarly, female patients were also under-represented in previous studies evaluating anatomical snuffbox as a vascular access site in patients undergoing PCI.,3 Importantly, female patients are well known to have a lower vascular caliber, ${ }^{4}$ more fragile tissue characteristics and a higher propensity for arterial spasm potentially leading to higher rates of complications during conventional radial artery cannulation. Difficulties might be relatively higher in female patients during arterial cannulation at the anatomical snuffbox due to the more delicate nature of this region.

Second, radial artery diameters at the anatomical snuffbox were reported to be considerably lower on ultrasonographic (USG) examination (compared with those at the conventional radial artery access site in the overwhelming majority of cases). ${ }^{4}$ This might warrant routine USG evaluation before radial artery cannulation at the anatomical snuffbox to determine subsequent strategies (selecting appropriate sheath size, crossover to other access sites, where necessary, due to poor anatomical features, etc.), and hence; to avoid potential complications. ${ }^{4}$ We also hold the opinion that USG might serve as a viable imaging modality in this setting, at least in female patients, those with relatively lower arm circumference, and those with previously failed arterial cannulations at the anatomical snuffbox. Accordingly, we wonder about the authors' attitude toward USG examination in their cases.

Third, the authors ${ }^{1}$ did not report any significant complications, including radial artery occlusion or crossover to other potential access sites due to arterial cannulation failure, etc. However, adverse outcomes in this setting might be more prevalent in real life and strongly depend on the operator's experience and patient characteristics. Within this context, specific strategies, including ulnar artery compression before conventional radial artery cannulation (with the potential to increase success rates of cannulation) and cutaneous application of local anesthesia at the access site (for the prevention of possible radial artery spasm) were previously suggested to be of significant benefit in the setting of conventional radial artery cannulation. ${ }^{5,6}$ Interestingly, these strategies might offer more significant advantages during arterial cannulation at the anatomical snuffbox.

In conclusion, radial artery cannulation at the anatomical snuffbox is a promising strategy in cardiovascular interventions, including CAG and PCI. However, it still needs to be further tested in highrisk patients (including female patients, those with apparently poor anatomical features, etc.). Moreover, USG evaluation before arterial cannulation at this specific site might help guide the subsequent management strategies, particularly in these high-risk patients. However, further studies are still warranted to shed light on the potential utility of anatomical snuffbox as an access site during cardiovascular interventions.

Author Contributions: Concept - G.T.; Design - G.T., C.Ö., K.Y.; Supervision - G.T., K.Y.; Resources - G.T., C.Ö., K.Y.; Data Collection and/or Processing - G.T., C.Ö., K.Y; Analysis and/or Interpretation - G.T., K.Y.; Literature Review - G.T., C.Ö., K.Y.; Writing - G.T., C.Ö., K.Y.; Critical Review - G.T., K.Y.

Conflict of Interest: The authors have no conflicts of interest to declare.

Address for Correspondence: Gökay Taylan, Department of Cardiology, Trakya University School of Medicine, Edirne, Turkey

e-mail: taylan1091@hotmail.com

Received: January 7, 2021 Accepted: February 4, 2021 • DOI: 10.5152/balkanmedj.2021.21025

Available at www.balkanmedicaljournal.org

ORCID iDs of the authors: G.T. 0000-0000-0000-0000; C.Ö. 0000-0000-0000-0000; K.Y. 0000-0000-0000-0000.

Cite this article as:

Taylan G, Öztürk C, Yalta K. Radial artery cannulation at the anatomical snuffbox: Hype or hope in interventional cardiology?. [published online ahead of print, 2021 June 4]. Balkan Med J. 2021;38(4):251-252

Copyright@Author(s) - Available online at http://balkanmedicaljournal.org/ 


\section{REFERENCES}

1. Soydan E, Akın M. Left distal radial artery access site in primary percutaneous coronary intervention: is it safe? Balkan Med J. 2020;37(5):276-280. [CrossRef]

2. Roghani-Dehkordi F, Hashemifard O, Sadeghi M, et al. Distal accesses in the hand (two novel techniques) for percutaneous coronary angiography and intervention. ARYA Atheroscler. 2018;14(2):95-100. [CrossRef]

3. Soydan E, Akın M. Coronary angiography using the left distal radial approach - an alternative site to conventional radial coronary angiography. Anatol $J$ Cardiol. 2018;19(4):243-248. [CrossRef]
4. Naito T, Sawaoka T, Sasaki K, et al. Evaluation of the diameter of the distal radial artery at the anatomical snuff box using ultrasound in Japanese patients. Cardiovasc Interv Ther. 2019;34(4):312-316. [CrossRef]

5. Yilmaztepe MA, Yilmaz E. Effect of transient ulnar artery compression on radial artery diameter. Exp Ther Med. 2018;16(4):3735-3739. [CrossRef]

6. Tatlı E, Y1lmaztepe MA, Vural MG, et al. Cutaneous analgesia before transradial access for coronary intervention to prevent radial artery spasm. Perfusion. 2018;33(2):110-114. [CrossRef] 